\title{
高圧燃料ポンプの摺動部に発生する接触荷重の定量化*
}

\author{
有冨 俊亮 ${ }^{* 1}$, 徳尾 健一郎 ${ }^{* 1}$, 宮崎 勝巳 ${ }^{* 2}$
}

\section{Quantification of Contact Force on Sliding Area of High-Pressure Fuel Pump}

\author{
Shunsuke ARITOMI ${ }^{* 1}$, Kenichiroh TOKUO and Katsumi MIYAZAKI \\ ${ }^{* 1}$ Hitachi LTD, Hitachi Research Laboratory \\ Horiguchi 832-2, Hitachinaka-city, Ibaraki, 312-0034 Japan
}

\begin{abstract}
Direct Injection engines have strongly penetrated the gasoline engine market for their benefits of reduction in fuel consumption. A high-pressure gasoline pump is one of the important components of a DI engine. A recent trend for the pump is to increase the operating pressure. The challenge to increase the operating pressure withstands load design of sliding area. The purpose of this research was to provide a measurement method of contact force on sliding area for load design. We proposed an estimation method of contact force by measuring the strain of the plunger, and installed it into the pump. It was difficult to measure the strain because the plunger is in the engine oil and moves up and down very fast. In addition, we proposed a new design to reduce the contact force and tested its effect by using the measuring method.
\end{abstract}

Key Words : Fuel Pump, Direct Injection Engine, Contact Force, Sliding Area, Strain Gage

\section{1. 緒言}

世界的に強まる温暖化防止の要求から自動車エンジンの省燃費化が求められている．これを受け，エンジン筒 内に燃料を直接噴射する筒内直接噴射エンジンが，高効率で環境負荷の低いエンジンの 1 つとして注目されてい る. 図 1 に筒内直接噴射エンジンの断面図を示寸．筒内直接噴射エンジンでは本報で研究対象とする高圧燃料ポ ンプで加圧した燃料を，インジェクタを用いてエンジン筒内に直接噴射し，空気と混合したのち点火プラグによ り点火して燃焼させる. 近年, 高圧燃料ポンプには, 低コストで小型な単筒プランジャポンプ(以降, 単筒ポンプ と称する)が採用されることが多く，その大流量化や低騒音化などを目指して，これまでに活発な研究(1)がなされ てきた.

現在はこれらに加え, 次期排気規制に対応するため, 単筒ポンプの吐出圧力が高められる傾向にある.ここで, 単筒ポンプの吐出圧力が高まると, それにともない摺動部の負荷が増大寸るため, 信頼性の観点からこの耐荷重 設計が課題となる. 本研究では, 耐荷重設計に向けたツールとして, ポンプが実際に動作している状態(以降, 実 動状態と称する)における，摺動部接触荷重の定量化手法を構築することを目的とした．

各種ポンプに関する実動計測手法として，斜板式複筒ピストンポンプなどにおいて可動部の挙動を非接触変位

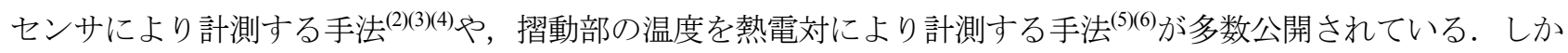
しながら，可動部に作用する力を実動状態で計測する手法は，筆者の把握する限り公開されていない.

本研究では，プランジャに作用する曲げ荷重を複数のひずみゲージを組み合わせることで計測し，その結果か ら摺動部の接触荷重を推定するという手法を考案し，単筒ポンプへの実装を試みた。ここで，ひずみゲージの貼 付箇所は油中であり，高速で往復動するため，実装する上で工夫が必要であった．また最後に，本手法の活用例 として，新構造の試作評価結果も紹介する.

\footnotetext{
* 原稿受付 2012 年 5 月 6 日

${ }^{* 1}$ 正員, (株) 日立製作所 日立研究所（テ312-0034 茨城県ひたちなか市堀口 832-2）

*2 日立オートモティブシステムズ(株)

E-mail: shunsuke.aritomi.ts@hitachi.com
} 


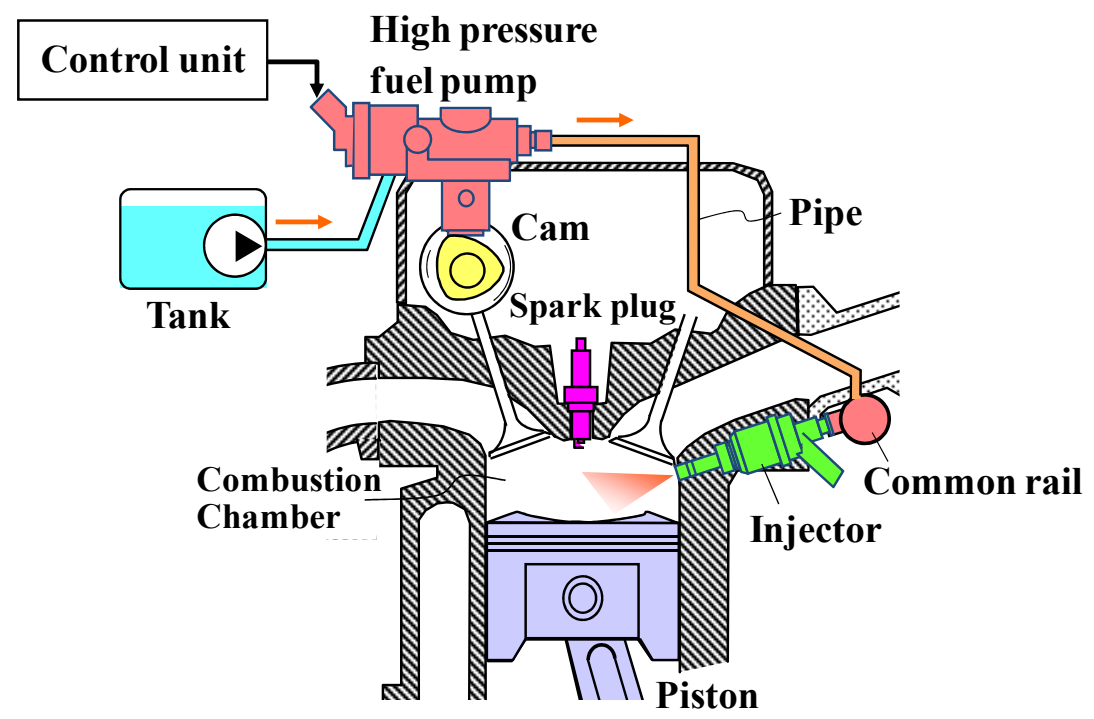

Fig.1 Direct injection engine

\section{2. 記号}

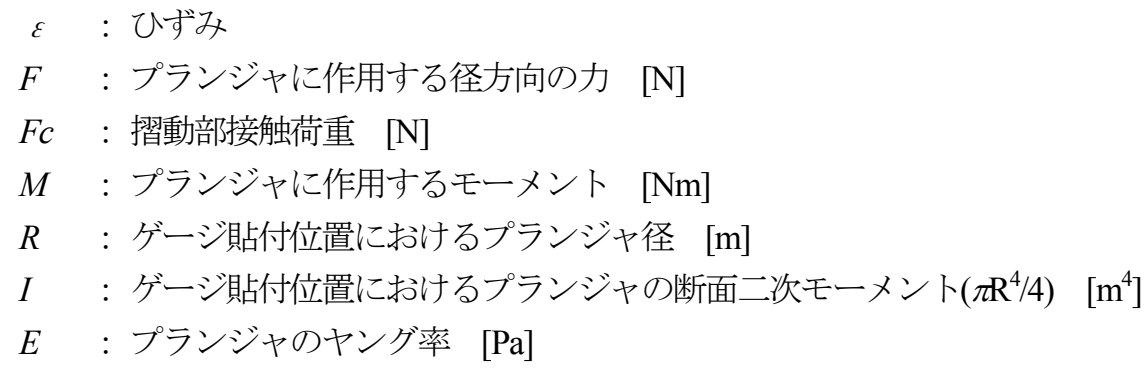

\section{3. 高圧燃料ポンプの動作および接触荷重の要因}

図 2 に単筒ポンプの基本構成を示寸. 単筒ポンプはカムによって駆動され, 動作部品はタペット, プランジャ, 戻しばね（以降，単にばねと称する)，吸入弁，吐出弁からなる，単筒ポンプはエンジンヘッドに設置され，吸気 弁または排気弁駆動用のカムシャフトに設けられたポンプ駆動用カムにより駆動される．プランジャは，その側 面を円筒状の摺動部に支持されており，軸方向に摺動可能である．また，その先端はタペットを介してカムに接 しており，その回転に従い往復運動をする，このとき，カム，タペット，プランジャの接触が保たれるように， プランジャにはばねが設けられている，単筒ポンプには，燃料タンク内にあるフィードポンプから燃料が供給さ れる.供給された然料は, プランジャの下降とともにダンパー室および吸入弁を介してポンプ室に吸い込まれる. プランジャが上昇を開始すると吸入弁は閉弁を開始し，完全に閉弁すると燃料が加圧される．ポンプ室内圧力が 高圧配管圧力を超すと，吐出弁が開きはじめ，高圧側へ燃料が供給される．燃料を加圧する際，プランジャには 軸方向に大きな圧縮反力が作用する.

以上のように構成される単筒ポンプにおいて, 摺動部に作用する接触荷重 $F_{c}$ の要因は主に以下の二点と考えら れる.

1. 圧縮反力によりプランジャ先端に発生する偏荷重 $F_{p}$

2.ばねから発生する横荷重 $F_{s p}$

それぞれの要因について以下に説明する. 前記要因 1 はプランジャとタペットの傾きにより, 両者の当接面が 片当たりする状態となり，プランジャに作用する軸方向の力の作用点がプランジャの中心軸からずれることによ 
り発生するモーメントである．プランジャに作用する軸方向の力は，燃料加圧時にはポンプ室内の燃料圧力によ る反力と戻しばねの弾性力の合力となり，非加圧時には戻しばねの弾性力のみとなる.

前記要因 2 はばねを軸方向に圧縮する際発生する径方向の力（以降，横荷重と称す）がリテーナを介してプラ ンジャ先端に作用する力である，一般的な押しばねの場合，座巻きに方向性があるため，垂直に圧縮すると端部 に横変位が発生し(7), これを拘束すると径方向に横荷重が発生する.

以上で説明した $2 つ の$ 要因により発生する接触荷重は方向が一致すれば足し合わされることになるため，それ ぞれの作用する方向も極めて重要な要素となる.

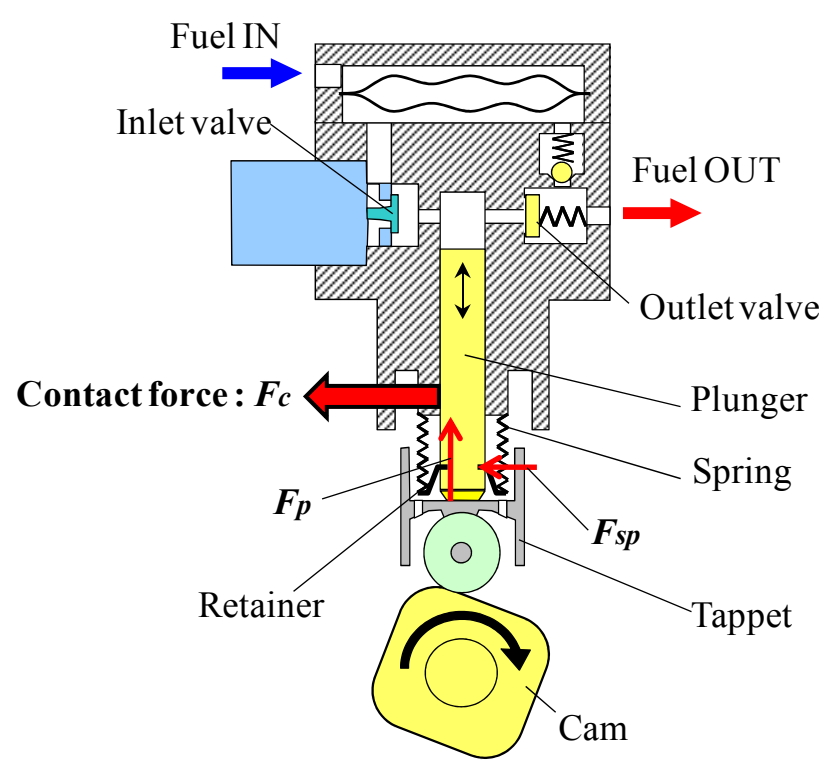

Fig.2 High-pressure fuel pump

\section{4. 接触荷重計測手法の構築}

\section{$4 \cdot 1$ 計測原理}

摺動部に作用する接触荷重を計測するために，プランジャのひずみを計測するという手法を採用した．なお， 同様の計測手法としては，農用車輪の車軸に作用寸る荷重の計測方法 ${ }^{(8)}$ が知られている.

計測の原理を説明する．まず，プランジャの細径部に $90^{\circ}$ おきに 4 枚のひずみゲージを貼り付ける. それぞれ のひずみゲージは，プランジャ上方から見て時計回りにCh1〜Ch4 とした. すなわち Ch1 と Ch3, Ch2 と Ch4 が それぞれ対面する配置となる．プランジャに径方向から力が作用すると作用側に引張ひずみが，反対側に絶対值 が等しい圧縮ひずみが発生する. 図 3 に径方向の力 $F$ が作用した際のひずみを実測した結果を示す. 摺動長を $L_{1}$, 摺動部の下端から力 $F$ の作用点までを $L_{2}$, ひずみゲージの貼付位置から力 $F$ の作用点までを $L_{3}$ と定義した. そ れぞれのひずみゲージ方向から $F$ を印加し，発生する引張ひずみを計測した．両者の関係は線形となり， $F=50 \mathrm{~N}$ でひずみが $45 \mu$ strain 程度となる。この実測結果は式(1)により求まる理論值とほぼ一致しており，この関係を用 いて計測したひずみから $F$ を求めることができる. そして, 式(2)と式(3)から式(4)のように摺動部接触荷重 $F_{c}$ を 求める. $L_{2}$ はプランジャの往復動により変動する值であるが，プランジャ全長に対して往復動長が十分に小さい ため，往復範囲の中心における值を用いて計算している.

$$
\begin{aligned}
& \varepsilon=\frac{F \times L_{3} \times R}{I \times E} \\
& F=F_{c}-F_{c 2}
\end{aligned}
$$




$$
\begin{aligned}
& F_{c} L_{2}=F_{c 2}\left(L_{1}+L_{2}\right) \\
& F_{c}=\frac{L_{1}+L_{2}}{L_{1}} F
\end{aligned}
$$

また，ポンプ実動状態では径方向の力に加え，軸方向にも力が作用する．向かい合うひずみゲージの出力の平 均值が軸方向の成分となるため，実動状態ではこの成分をそれぞれのひずみゲージ出力から差し引いて径方向の 力による曲げ成分のみを出力する，一例として，Ch1 の場合に関して具体的に説明する. Ch1 と Ch3 のひずみを それぞれ $\varepsilon_{1}$ と $\varepsilon_{3}$ とすると，式(5)のように Ch1 の出力から Ch1 と Ch3 の平均值を引いたものが，Ch1 の径方向 の力による曲げひずみ $\varepsilon_{1}$ となる. したがって, 式(1)の $\varepsilon$ を $1_{1}$ 'とすることで, 径方向の力 $F$ を求めることがで きる.

$$
\varepsilon_{1}^{\prime}=\varepsilon_{1}-\frac{\varepsilon_{1}+\varepsilon_{3}}{2}
$$

ここまでは，Fがちようど各ひずみゲージ方向から作用したと仮定して説明を進めてきたが，各ひずみゲージ 間の方向から作用した場合について，以下に説明する．図４に荷重方向を定義する座標系を概略図で示した．プ ランジャとカムの間にはローラータペットが存在するが，本図では便宜上省略している．カム軸方向を $x$ 軸，そ れと直行する方向を $y$ 軸と定義する. まず，前述の手法で求めた $x$ 方向と $y$ 方向のそれぞれの摺動部接触荷重 $F_{c x}$ および $F_{c y}$ を求め，それらを式(6)のように合成し，合力ベクトル $F_{c}$ の絶対值を算出する．計測結果は，ベクトル $F_{c}$ の頂点を $x y$ 平面上にプロットし，軌跡として表示することとした.

$$
F_{c}=\sqrt{F_{c x}^{2}+F_{c y}^{2}}
$$
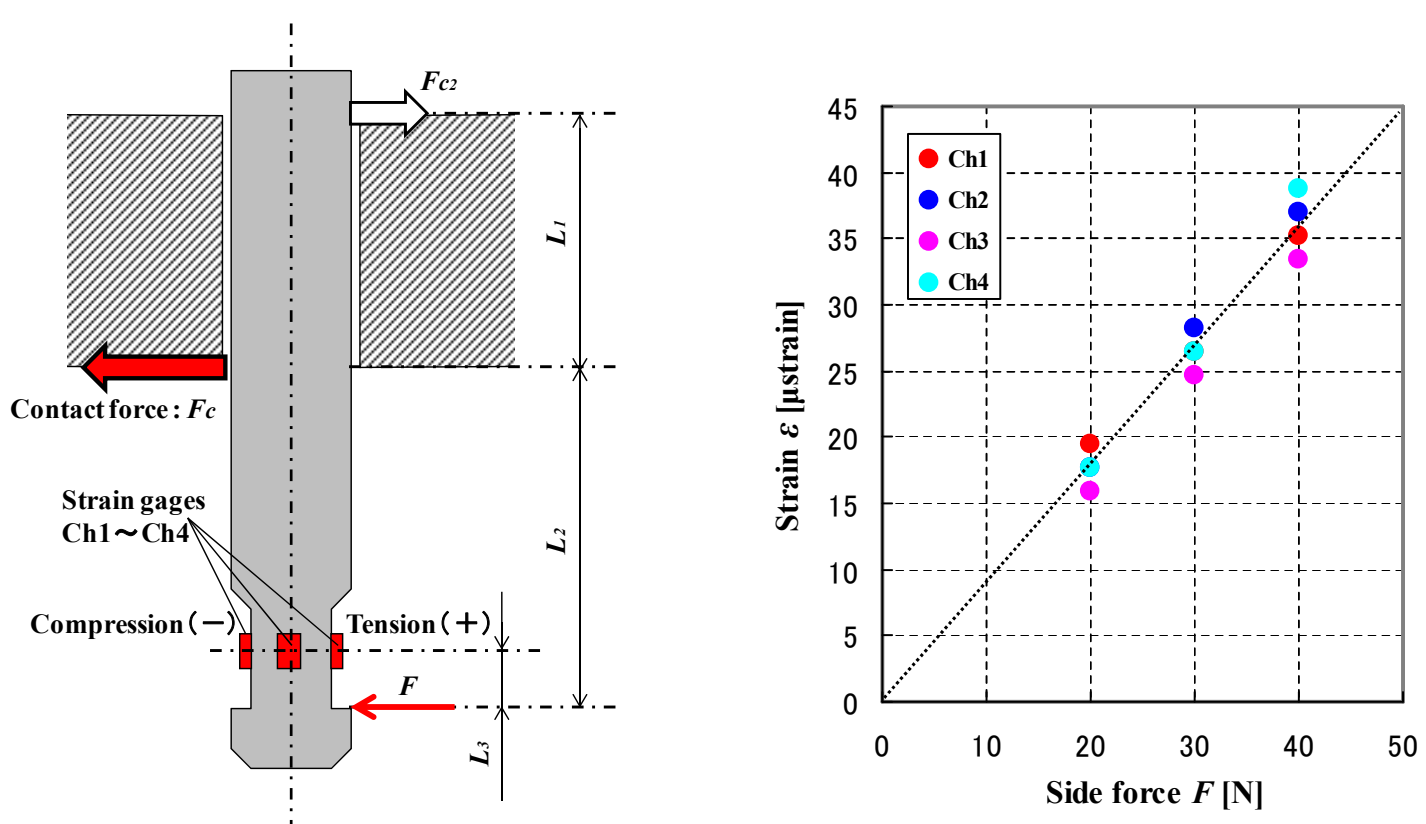

Fig.3 Relationship between side force and strain

\section{$4 \cdot 2$ 実機へのひずみゲージの実装方法}

図 5 に実装方法の概略図を示す，実機にひずみゲージを実装，配線するに当って複数の課題がある．まず，ひ ずみゲージを貼る部位はエンジンオイルにさらされるため，何らかの方法でひずみゲージの接点を絶縁しなけれ ばならない，また，ばねの内径に触れないように実装しないと配線がばね線間に挟まれる危険性があるため，実 
装スペースにも大きな制約がある，そこで，耐油コーティング剤で接点上に薄いコーティングを施す方法を採用 した．また，プランジャは最大 $200 \mathrm{~Hz}$ 以上で高速に往復動し，ストロークも最大で数 $\mathrm{mm}$ 程度ある. このため, ひずみゲージの配線が切断しないように工夫する必要がある。この点に関しては, 配線の仕様と固定および取り 回し方法を的確に選定することで対応した．配線仕様は配線径，配線タイプ，被覆材質といった項目をそれぞれ 検討した結果, 配線径 $\phi 0.8,2$ 線ヨリ線タイプ, ビニール被覆のものを採用した. また, 配線の固定および取り 回しに関しては，前述した耐油コーティングの上に配線を巻き付け，さらに耐油コーティングを二度塗りするこ とで固定し，耐久性を確保した．固定部から先の配線に関しては，ばねの内側を通し，プランジャのまわりをら せん状に配置する．こうすることで，プランジャがストロークした際に配線がばねのように変形し，局所的な負 荷が発生しづらくなる．さらに，ポンプ本体には配線を外部に取り出寸ための通路を追加工寸る必要がある.

以上までで外部に導かれた配線は，端子台を経由して 3 線リード線により延長され，ブリッジボックスへと接 続される．この際，延長した 3 線部分への温度影響がキャンセルされるように接続する．ここで，望ましくはポ ンプ内部も含めて全ての配線を 3 線にするべきであるが, 実装スペースおよびプランジャ動作に対する耐久性と いった面で困難があり，本手法ではポンプ内部の配線に 2 線リード線を用いている．しかしながら，試験ベンチ でモーターによりポンプを短時間駆動する場合, エンジンオイル温度の上昇が微量であるため, 影響は小さいと 想定される. 実車やエンジンベンチ等のファイアリングしたエンジンで計測を行う場合, この影響が大きいため, 全域において 3 線ゲージを用いることが望ましい.

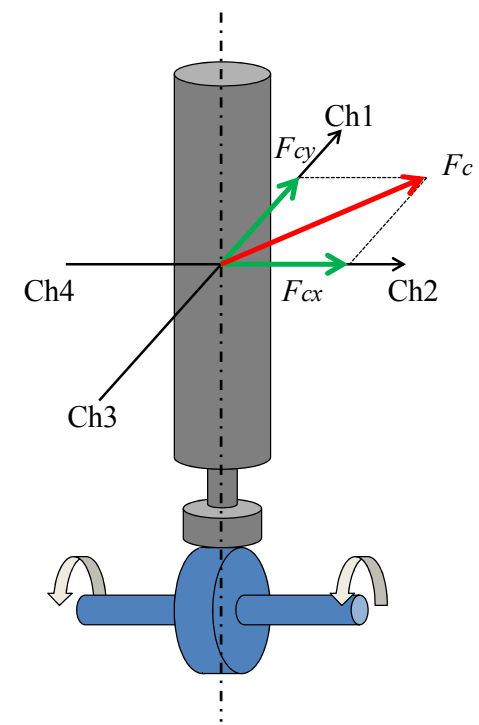

Fig.4 Definition of coordinate

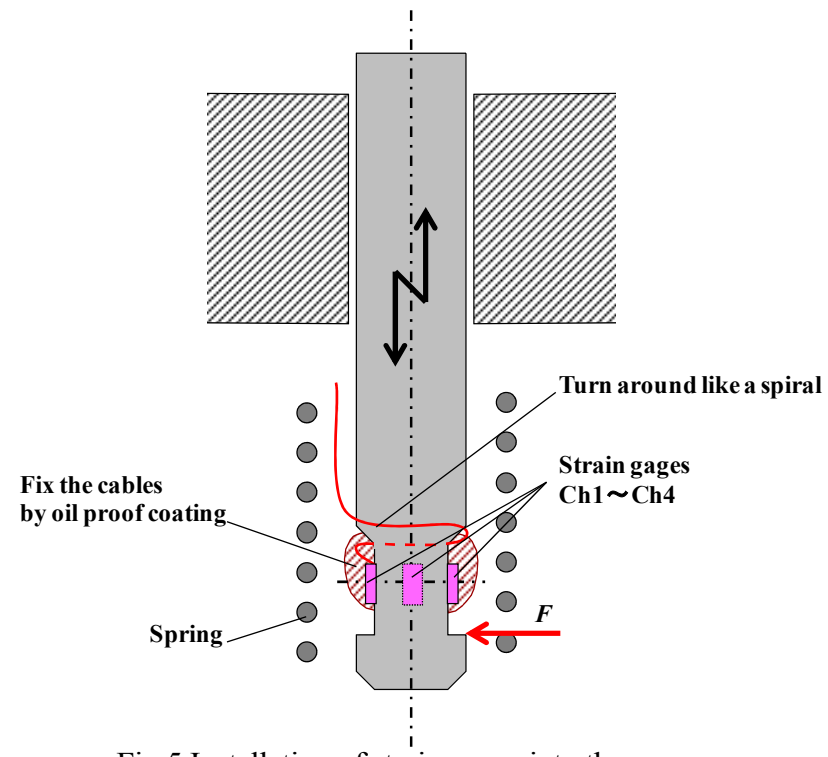

Fig.5 Installation of strain gages into the pump

\section{5. 接触荷重の計測結果と分析}

\section{$5 \cdot 1$ 接触荷重計測結果}

図 6 および図 7 に接触荷重計測結果を示した. 試験用ポンプはばねの巻き終わりが Ch1 方向を向くように統一 して組み立てた．試験条件は吐出流量がゼロの場合，すなわち吐出圧力が $0 \mathrm{MPa}$ の場合と，最大流量で吐出圧力 が $5 \mathrm{MPa}$ の場合と $10 \mathrm{MPa}$ の場合の計三通りとした．なお，カ厶軸回転数は 800rpm で，一定とした.

図 6 には接触荷重 $F_{c}$ の時刻歴を示した. また, ポンププランジャの動作タイミングを示すレファレンス信号(以 降，Ref信号と称する)も併記した. Ref信号の立ち上がりがプランジャの上死点(以降, TDC : Top Dead Center と 称する)を示している.

結果を見ると，プランジャ動作に伴い接触荷重が周期的に変動していることが分かる. プランジャに圧縮反 力が作用する加圧工程では，吐出圧力の増加とともに接触荷重も増加していることが確認できる．対する吸入工 程では，圧縮反力が作用しないため吐出圧力により接触荷重に差は見られない.

以上のように，概ね想定通りに変動する接触荷重を計測することができ，そのオーダーは合力で $100 \mathrm{~N}$ 弱であ ることが分かる. 
また, 図 7 には図 6 の結果を接触荷重 $F_{c}$ のベクトル頂点の軌跡で表示した. TDC をO印で, 下死点(以降, BDC : Bottom Dead Center と称する)を $\triangle$ 印で示している.

\section{$5 \cdot 2$ 先端偏荷重による影響}

プランジャ先端に作用する偏荷重は，プランジャに作用する圧力に比例する．すなわち，吐出圧力が増加する とそれに伴い増加するはずである．このため，プランジャに圧力が作用する加圧工程に着目して，吐出圧力の異 なる結果を比較する. 図6で比較すると, プランジャにほとんど圧力が作用しない $0 \mathrm{MPa}$ に比べ, 吐出圧力が $5 \mathrm{MPa}$, $10 \mathrm{MPa}$ と増加していくと, 接触荷重 $F_{c}$ が $30 \mathrm{~N}$ 程度ずつ増加していることが分かる. この増加分が先端偏荷重に より発生する接触荷重であると推定される. また図 7 から吐出圧力の増加に伴い，力ムの駆動方向である Ch1 の 方向に比較的大きな接触荷重変動が見られる.これは, プランジャ先端偏荷重 $F_{p}$ の原因となる片当たりがカムの 摇動方向に発生しやすいからであると推定される.

\section{$5 \cdot 3$ ばね横荷重による影響}

ばねから発生する横荷重は，プランジャに作用する圧力には関係しない．このため，図 6 に記載の $0 \mathrm{MPa}$ の接 触荷重に着目寸る。 $0 \mathrm{MPa}$ の接触荷重は, プランジャの往復動, 寸なわちばねの伸縮に伴い変動しており, 最大 で $F_{c}=40 \mathrm{~N}$ 程度となっている.これが，ばね横荷重 $F_{s p}$ により発生する接触荷重であると推定される. また図 7 か ら，BDC から TDCへばねを圧縮することで，接触荷重が Ch1 の方向へ増加していることが分かる．計測に用い たポンプは, ばねの巻き終わりをCh1 方向に向けて組み立てており, これに影響を受けて接触荷重が Ch1 の方向 へ増加しているものと推定される.

Contact force, $F_{c}[\mathrm{~N}]$

Reference

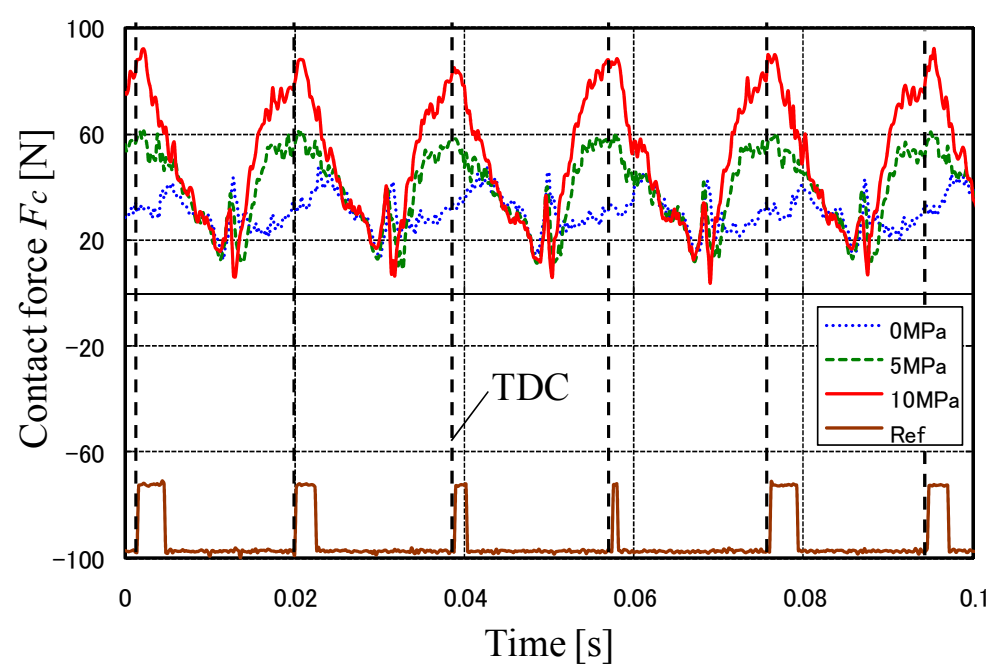

Fig.6 Time chart of contact force (current design)
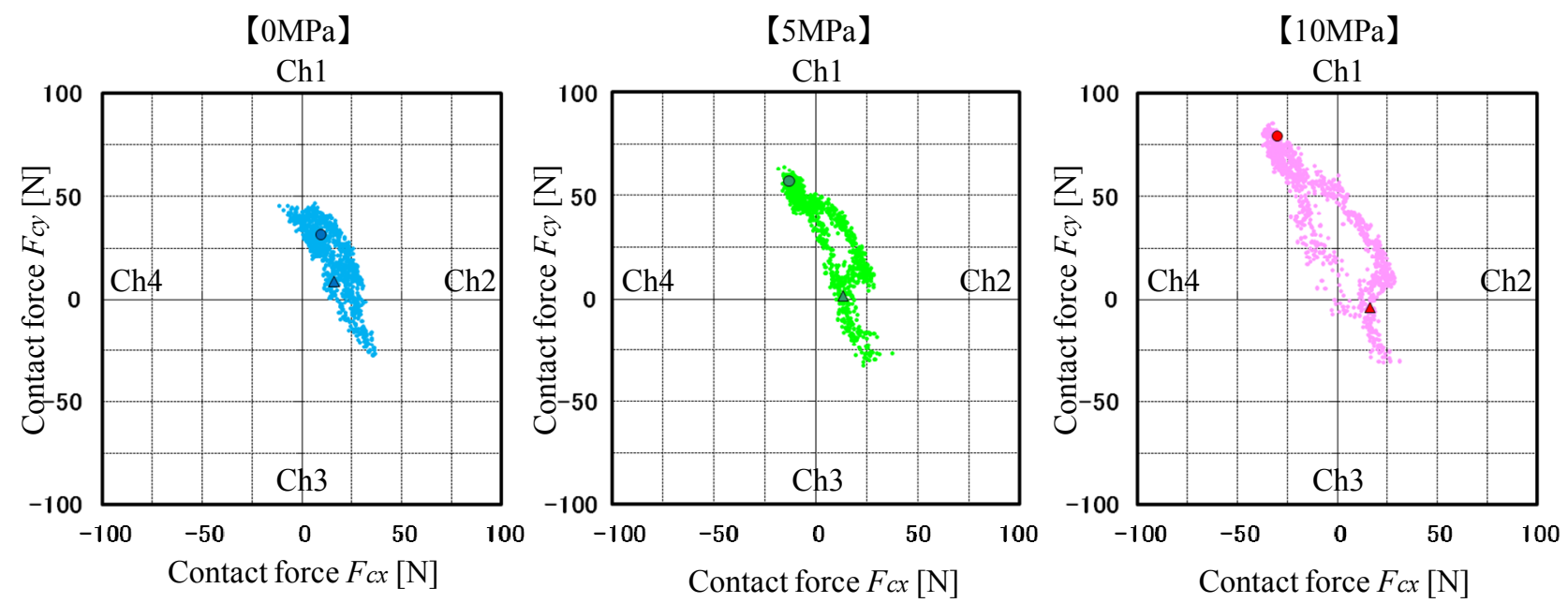

Fig.7 Orbit of contact force (current design) 


\section{6. ばね横荷重遮断構造の試作と検証}

\section{$6 \cdot 1$ ばね横荷重遮断構造のコンセプト}

前章までで構築した接触荷重計測手法を新構造の試作評価に活用した例を紹介寸る．新構造のコンセプトは接 触荷重を発生させる要因の一つであるばね横荷重 $F_{s p}$ をプランジャから遮断するというものである. 図 8 に従来 構造と新構造の加圧工程中における挙動を示寸. 従来構造では, ばね荷重がリテーナからプランジャを経由して タペットに伝わる構造となっているのに対し，新構造ではプランジャとリテーナの間に隙間を形成し，ばね荷重 が直接リテーナからタペットに伝わる構造となっている．これにより $F_{s p}$ がプランジャに作用しないため，接触 荷重 $F_{c}$ が低減できると考えられる，なお，吸入工程ではタペットの下降動作により，タペットがプランジャから 離間する．そして，プランジャとリテーナが接触してプランジャが下降を開始する構造となっている.

\section{$6 \cdot 2$ 効果の検証}

前節で説明した構造の効果を, 接触荷重計測手法を用いて検証した結果を図 9 および図 10 に示す. 試験条件は 図 6 および図 7 と同様とした．図 9 にてプランジャに圧力が作用しない $0 \mathrm{MPa}$ の結果に着目すると, 接触荷重は 概ね $10 \mathrm{~N}$ 以下となり，従来品では 40N 程度であったばね横荷重による接触荷重を，大幅に低減できていることを 確認した．また図 10 に示寸軌跡も原点付近で変動しており，BDC から TDCへばねを圧縮しても $F_{c}$ の増大を抑 制できていることが分かる.

なお，本構造ではタペットとプランジャの間に隙間があるため，タペットの往復動距離に対して，プランジャ の往復動距離が小さくなる. その結果, プランジャの押しのけ容積が低下し, 吐出流量が低下してしまう.また, 往復動にともない各部が衝突するため, 而久性の検証が今後の課題となる.

口revious design

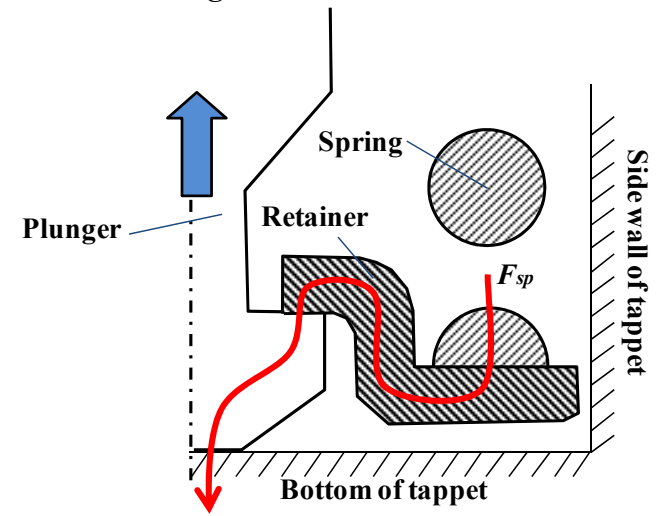

New design

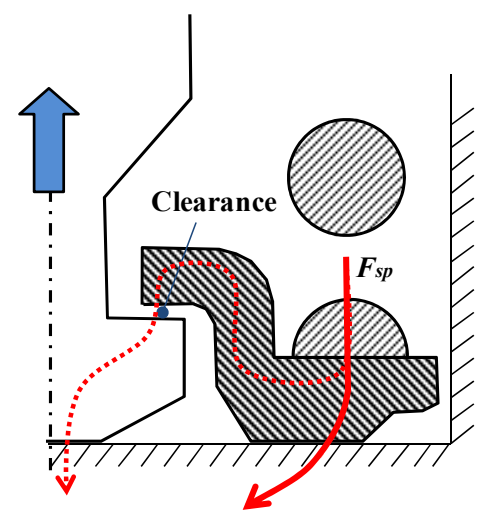

$\longrightarrow$ : Force transfer pass

Fig.8 Concept of new design to cut off the spring side force

Contact force, $F_{c}[\mathrm{~N}]$

Reference

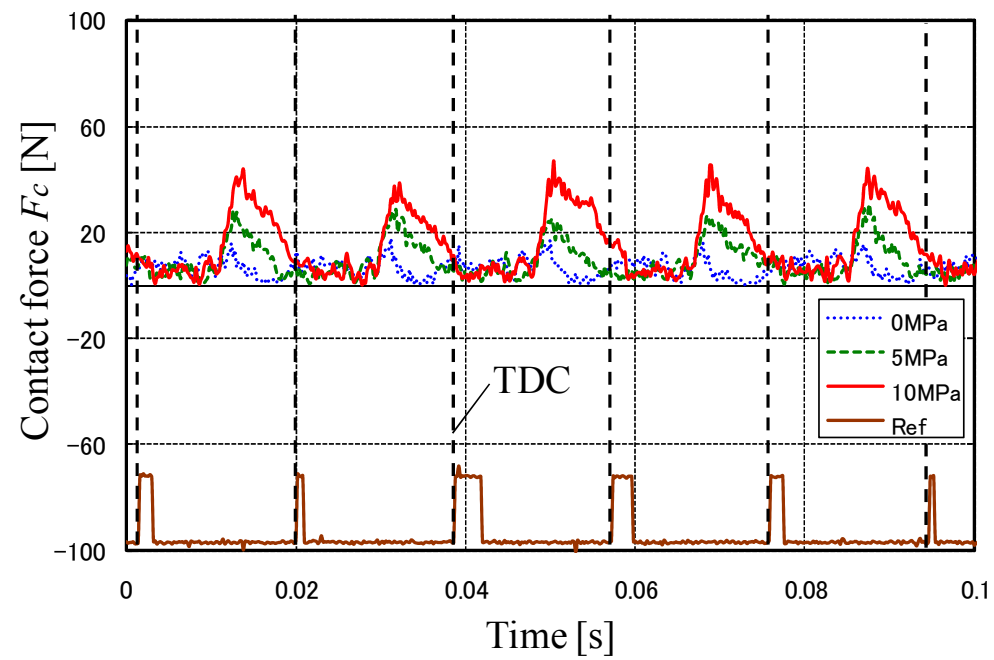

Fig.9 Time chart of contact force (New design) 

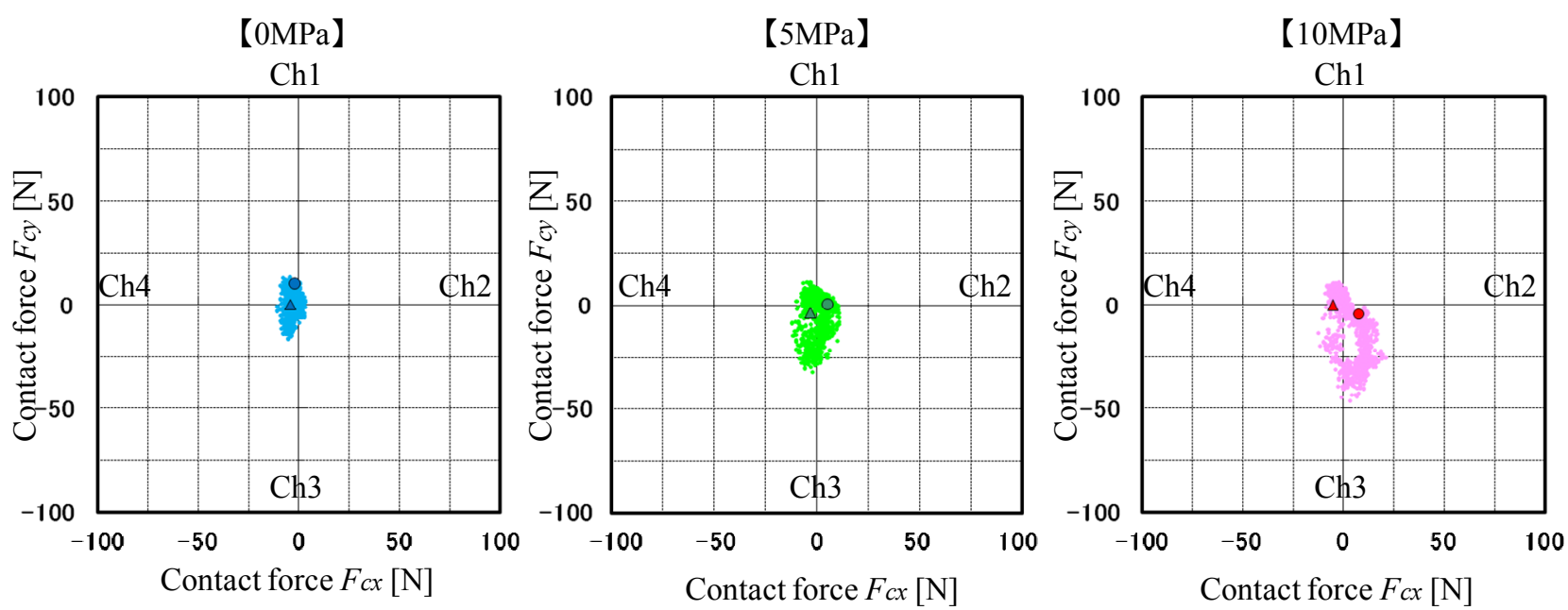

Fig.10 Orbit of contact force (New design)

\section{7. 結語}

本研究では，筒内直接噴射エンジン向け単筒プランジャポンプの摺動部接触荷重を定量的に評価する手法を検 討し，以下の結論を得た.

1.プランジャに作用する曲げ荷重を，複数のひずみゲージを組み合わせて計測することで，動作中のポンプにお いて摺動部の接触荷重を推定する手法を構築した.

2. 上記手法を用いて従来品の接触荷重を定量化した結果，プランジャ先端の偏荷重に起因して発生する接触荷重 は，吐出圧力が $5 \mathrm{MPa}$ 増加するごとに $30 \mathrm{~N}$ 程度増加すること，また，ばねから発生する横荷重に起因して発生 する接触荷重は $40 \mathrm{~N}$ 程度であることが分かった。

3. 上記手法の活用例として, 新しく考案したばね横荷重遮断構造の試作評価を実施した。評価の結果，コンセプ 卜通りの挙動を確認し，ばね横荷重に起因して発生する接触荷重を $10 \mathrm{~N}$ 以下に低減できることを実証した.

\section{文献}

(1) Tokuo, K., Yamada, H., Usui, S., Abe, M., and Aritomi, S., "Development of high Pressure Fuel Pump for GDI Engine", FISITA World Automotive Congress 2008, F2008-06-191 (2008)

(2) 井星正氣，山口惊，“斜板式ピストンポンプモータに用いられるスリッパ軸受の特性”，日本機械学会論文集 B 編, Vol. 49, No. 437 (1983), pp. 164-171.

（3）田中嘉津彦，京極啓史，中原綱光，“球面弁板を有する斜軸式ピストンポンプのロータ挙動の測定”, 日本機械学会 論文集 B 編，Vol. 60, No. 569 (1994), pp. 201-207.

（4）大久保浩志, “斜板式ピストンポンプ・モータにおけるスリッパ軸受の回転速度測定”, 日本機械学会 2001 年度年 次大会講演論文集(2001), pp. 121-122.

(5) 風間俊治, “斜板式アキシアルピストンポンプのしゅう動部の温度測定”, 日本機械学会 2005 年度年次大会講演論 文集(2005), pp. 285-286.

（6）風間俊治，佐々木隼斗，“斜板式アキシアルピストンポンプの熱潤滑特性”, 日本機械学会論文集 C 編, Vol. 75 , No. 758 (2009), pp. 2797-2802.

（7）日本ばね学会編，ばね，第4版 (2008)，p.186，丸善株式会社.

(8) 岸本正, 坂井純, 谷口哲司, 石本和重, “農用ラグ車輪用外力測定装置の開発(第 1 報)”, 帯広畜産大学学術研究報 告, 第 I 部 (1991), pp. 271-277. 